\title{
Elimination of Excess Capacity in Monopolistic Competition: An Alternative Approach
}

\author{
Mohammed Saiful Islam ${ }^{1}$ \\ ${ }^{1}$ Department of Economics, University of Chittagong, Bangladesh \\ Correspondence: Dr. Mohammed Saiful Islam, Professor, Department of Economics, University of Chittagong, \\ Bangladesh.
}

Received: April 8, 2019

Accepted: April 23, 2019

Online Published: April 26, 2019

doi:10.20849/iref.v3i1.568

URL: https://doi.org/10.20849/iref.v3i1.568

\begin{abstract}
Monopolistic competition is a real life market structure in which the elements of both perfect competition and monopoly exist. The paper examines the properties of perfect competition and monopoly under the purview of both conventional and Islamic economics. It finds that perfect competition is permissible in Islamic economic framework but monopoly is not. Monopolistic competition, however, cannot be fully abolished because of its real life relevance. The main problem lying with the monopolistic competition is that each firm preserves the capacity of producing more than what they produce in equilibrium- this is generally known as excess capacity. The current paper proposes a model that eliminates excess capacity and shows how the monopolistically competitive firms may remain at an output level that is socially optimum. The proposed model is a modification of Chamberlin (1933) model. According to the proposed model, the firms will produce socially desirable output if they are given some incentives. Amount of required incentive is the difference between the cost of producing additional units of output and the profit foregone due to the deviation from profit maximizing output level.
\end{abstract}

Keywords: Chamberlin Model, excess capacity, monopolistic competition

\section{Introduction and Objective of the Study}

The existing literatures argue that monopoly is forbidden in Islam because the monopolist gets the chance of exploiting consumers by charging higher price or through limiting the supply. The Quranic terminology of monopoly is Ihtikar which comes from the word hakr. Hakr means collecting and controlling goods with the objective of raising price in future. Since monopolistic competition has the element of monopoly, it is likely to be prohibited in Islam. There is no direct verse in the Al-Quran forbidding Monopoly. However, in the Hadith, Prophet Mohammed (pbuh) mentioned that a lot of muhtakir (monopolists) are sinner. The reason of such direction is clear. Emergence of monopoly will give the right of undue authority to an individual producer or to a group. Conventional economics proves the existence of inefficiency in monopoly through the reduction in consumer and producer surplus. It is therefore evident that monopoly is bad from the views of both conventional and Islamic schools. But sometimes under special circumstances believers of Allah have to group together to monopolistic practices, which stands as the need of time. For example, Islamic Banking system in Bangladesh is monopolistic in nature. Only few banks are operating their activities under Islamic Shariah. Because of the existence of very few Islamic banks, they enjoy monopoly power but it is absolutely unintentional, and, of course, an action that could in no way be avoided. The same may occur in the product market.

The markets of most of the products meeting daily needs are monopolistically competitive in nature. In this type of market, many sellers sell close substitute products. Availability of close substitutes makes the demand for such products highly elastic. Under perfect competition demand is perfectly elastic because all products are same and therefore price is fixed. There are at least two advantages of perfect competition in product market that are not conflicting with Islamic Shariah. The first is optimal allocation of resources and second is the production of socially optimum output. Monopolistically competitive firms do not produce socially optimum output because they face downward sloping demand curve which can only be tangent to the average cost curve at a point to the left of minimum point of average cost curve. This suggests that monopolistically competitive firms produce an amount less than perfectly competitive firm. The difference of competitive output and monopolistically competitive output is traditionally known as excess capacity. The foremost criticism of aforementioned market structure is the presence of excess capacity which is a common feature of monopoly business. Since the products traded under 
monopolistically competitive environment are necessary ones, and their demands are need-based (Mannan, 1984), there is no way to stop the business despite its adherence to monopoly. Our current paper focuses how the monopolistically competitive market can be corrected in line with Islamic Shariah. The paper uses Chamberlin (1993) model to illustrate the equilibrium of monopolistically competitive firm and demonstrate excess capacity. Edward Chamberlin was the pioneer of introducing real life market structure in economics literature. There are three different models of Chamberlin showing equilibrium under monopolistic competition. Model-1 describes equilibrium with the entrance of new firm. Model-2 depicts equilibrium with price competition and Model-3 illustrates equilibrium with price competition, entry and exit. Subject matter of none of these three models is conflicting with Islamic Shariah since entrance of new firm is encouraged by Islamic Shariah because it lowers monopoly power. Again, price competition is also admissible because it goes in favour of the consumers. Of course, if price reduction is offered with the ill motive of driving the financially weaker firms out of the market then it is not acceptable. The principal limitation of the models is the presence of excess capacity. Interestingly, Chamberlin himself acknowledged that his firms preserve excess capacity. Our current paper proposes an Islamic approach of eliminating excess capacity of monopolistically competitive market without completely abolishing this real life market structure. This is the first ever attempt to modify Chamberlin's model of monopolistic competition for eliminating excess capacity in line with Islamic Shariah. Section II of the paper reviews literatures on various market structures from theoretical consideration. Section III illustrates three models of monopolistic competition introduced by Chamberlin and documents their criticism. Section IV proposes an alternative model under Islamic perspective and section $\mathrm{V}$ concludes.

\section{Literature Review}

Our current paper investigates the nature of monopolistic competition in product market. This type of market has the elements of both perfect competition and monopoly. The two extremes of product market are perfect competition and monopoly. In a perfectly competitive market large number of buyers and sellers trade homogeneous goods at a fixed price (Andrews, 1964). Long run equilibrium of perfect competition does not encompass any economic profit because of free entry and exit of firms. Careful investigation of perfect competition suggests that this type of market structure has better implication in socioeconomic perspective. This is because in perfect competition virtually competition does not occur. Although it sounds strange that perfect competition is devoid of competition but the properties of perfect competition make this clearer. Since large number of buyers and sellers trade homogeneous goods, price in perfect competition is fixed. Sellers have nothing that can create competition among themselves. From this viewpoint, perfect competition is admissible in Islamic economic system. Sometimes competition is thought to be prohibited in Islam which comes from misunderstanding of Islamic Shariah. In the holy Qur'an in surah Hud Allah says: Islam concerns on man's living and his livelihood. This verse laid down that there is prohibition to accumulate wealth in the hands of the few. The lesson of this verse is directly consistent with the feature of perfect competition where, not a few, rather large number of sellers sell same product. The main principles of competition in Islam are Maslahah, Sadd Zarai', Su isti'mal al-haq, Maqasid Shariah, Qawaid fiqh and Tawheedic.

Maslahah means benefit or interest. Technically it refers to the need to balance between private interests and the larger public interest, which complies with the objectives of the Shariah. Failure to preserve Maslahah is Mafsadah. For further clarification of Maslahah, Prophet Mohammed (pbuh) asserted, "A city dweller should not sell things to a desert dweller, leave people to obtain their livelihood from each other by the grace of God". The statement exemplifies the interest of different groups. City dwellers are assumed to be more knowledgeable than the rural people and therefore the formers are not allowed to exploit the latter. Competition policy of Maslahah preserves the interest of different groups. Saad al Dharai means blocking unfair competition. The principle of sadd al-dharai' is evident in Prophet's prohibition on monopoly or ihtikar. Islam also promotes the concept of $s u$ isti'mal al-haq, which means prohibition of any exercise of rights that lead to the infliction of real harm to others. Maqasid Shariah refers to the protection of the five interests of the Muslim. They are al-din (religion), al-nafs (soul), al-'aql (mind), al-nasl (descendents), and al-mal (property). Islam guarantees justice so that everyone gets his due for his contribution to society and that there is no exploitation of one individual by another. One Hadith from Muslim reads "Do not envy one another; do not inflate prices by overbidding against one another; do not hate one another; do not harbor malice against one another; and do not enter into commercial transaction when others have entered into that (transaction); but be you, O slaves of Allah, as brothers. A Muslim is the brother of another Muslim; he neither oppresses him nor does he look down upon him, nor does he humiliate him. Piety is here, (and he pointed to his chest three times). It is enough evil for a Muslim to hold his brother Muslim in contempt. All things of a Muslim are inviolable for his brotherin-faith: his blood, his property and his honor." This Hadith is the foundation of fair competition. Qawaid fiqhiah refers to legal maxim which is 
a key guideline for Muslim in determining several issues. Tawheedic approach is a philosophic foundation and added value to every muslim in preserving what Allah commands and what He forbids. It means God's unity and sovereignty or faith of Allah. Allah is our creator of this universe and all creatures. Therefore, as His servants in this world, we must submit our life wholeheartedly to Him alone. Ghani (2003) argues, the six principles of competition discussed above give rise to the acceptance of fair competition in trade. Perfectly competitive market is not devoid of the above principles and therefore there is no reason why perfectly competitive product market should be rejected. More importantly, perfect competition ensures optimum use of resources and maximum social welfare (Baumol and Blinder, 2005). The polar opposite of perfect competition is monopoly.

In monopoly single seller supplies a particular product to all consumers of an economy (Choudhury, 1986). Because of full discretion, monopolist earns supernormal profit in both short run and long run. Islam does not admit the existence of monopoly because this form of market structure involves welfare loss. Being the sole supplier, monopolist gets the chance of exploiting consumers and therefore Islamic economic system does not allow monopoly business. The Quranic terminology of monopoly is Ihtikar, which is prohibited in Islam. Ihtikar means a single person or company being the only producer of a commodity. The prohibition of Ihtikar is further justified by recognizing one hadith where Prophet has reminded that Allah will curse a person who monopolizes others. In another hadith reported by al-Tirmidhi, Prophet declared that: He who monopolizes is not but a wrongdoer. The closely related concept of Ihtikar is Iktinaz. Iktinaz refers to the case where shortages are created by holding large stocks of goods in warehouses and withholding them from sale. The motive is that to keep supply less than the demand and create artificial crisis in the market. Trader who can afford large sums of capital normally does this activity. In hadith narrated by Ibnu Majah is: "He is a criminal who hoards grain to sell it at higher price". In another hadith he said: "He also keeps back grain from sale for forty days only to sell it at higher prices, such a man is not aware of the existence of God or that God has cut himself off from him". Second caliph, Umar Ibn Al-Khattab imposed the additional amount of the monetary payments payable by the offender. The decision by Saidina Umar to impose penalty to the person who concealed the property showed that Islam always prevents any kind of deeds, which will lead to unfair competition such as economic crisis and inflation. All these bad features are present in monopoly business. Monopolist supplies a lower quantity of output at a higher price. Same occurs in the event of oligopoly.

If the number of seller is more than one but not many then the market turns out to be oligopolistic. According to Hawkins (1972) oligopolistic market hosts only small number of sellers and therefore the risk of collusion remains active. Collusive oligopoly is a kind of monopoly because the colluders act as a single seller and exploit the consumers. If the number of seller is large and each seller sells differentiated product then the market becomes monopolistically competitive. Presence of large number of sellers is the element of perfect competition and differentiated product of each seller generates monopoly power. Therefore, it is said that monopolistic competition is a blend of perfect competition and monopoly.

Product differentiation is the unique feature of monopolistic competition. Each seller tries to make his or her product different from other sellers' products. Advertisement and other selling activities are the devices of product differentiation. In most cases product differentiation is fancied in nature. Fancied differentiation refers to artificial differentiation of the product though the products are virtually identical. Sellers change the label of the product or resort to persuasive advertisement in order for making the product different. Real differentiation, however, occurs if the goods are different in their composition and quality. Whatever type of differentiation takes place, the main objective of product differentiation is to capture the market and gain profit. Islam seemingly does not admit monopolistic competition because of the presence of the element of monopoly. But in real life situation most of the products' markets are monopolistically competitive. Producers of necessary or quasi-luxury items behave as monopolistically competitive firms. We therefore put effort to make this type of market compatible with Islamic economic system.

Demand for the products traded under monopolistic competition is highly elastic because of the availability of a lot of close substitutes. E. H. Chamberlin (1933) has explained the equilibrium of monopolistic competition assuming downward sloping highly elastic demand curve and usual cost curve. Next section briefly discusses three different models of monopolistic competition proposed by Chamberlin. The distinguishing feature of all three models is the existence of excess capacity of the firms. Excess capacity refers to the difference between socially optimum output and actually produced output. The term excess capacity suggests that the firms are able to produce more than what they are actually producing. That means, each firm preserves capacity of producing more but they are not utilizing their full capacity and thereby society remains deprived of potential welfare. Our current paper takes a close look at each model and finds the existence of excess capacity in each of the models. 


\section{Three Models of Monopolistic Competition Proposed by Chamberlin}

The first model assumes that firms under monopolistic competition achieve equilibrium through entry alone. In the event of economic profit, new firms enter into the group and if they find the chance of loss then get out of the group. Figure 1 explains the mechanism of achieving equilibrium through the entrance of new firms. Initial equilibrium point is $\mathrm{E}$ where the typical firm is making an economic profit equals to the area $\mathrm{P}_{1} \mathrm{THR}$. Existence of economic profit allures new firms to enter that causes a leftward shift in the planned demand curve. Entry continues until the economic profit fully disappears. Finally the demand curve $\mathrm{CD}$ gets tangent with the average cost curve at point $\mathrm{G}$ where economic profit fully exhausts. Equilibrium price and output are $O \bar{P}$ and $O \bar{X}$ respectively. Although theoretically the model is beautiful, each firm under monopolistic competition is devoid of producing socially optimum output which is attributable to the minimum point of average cost curve.

\section{Model-1}

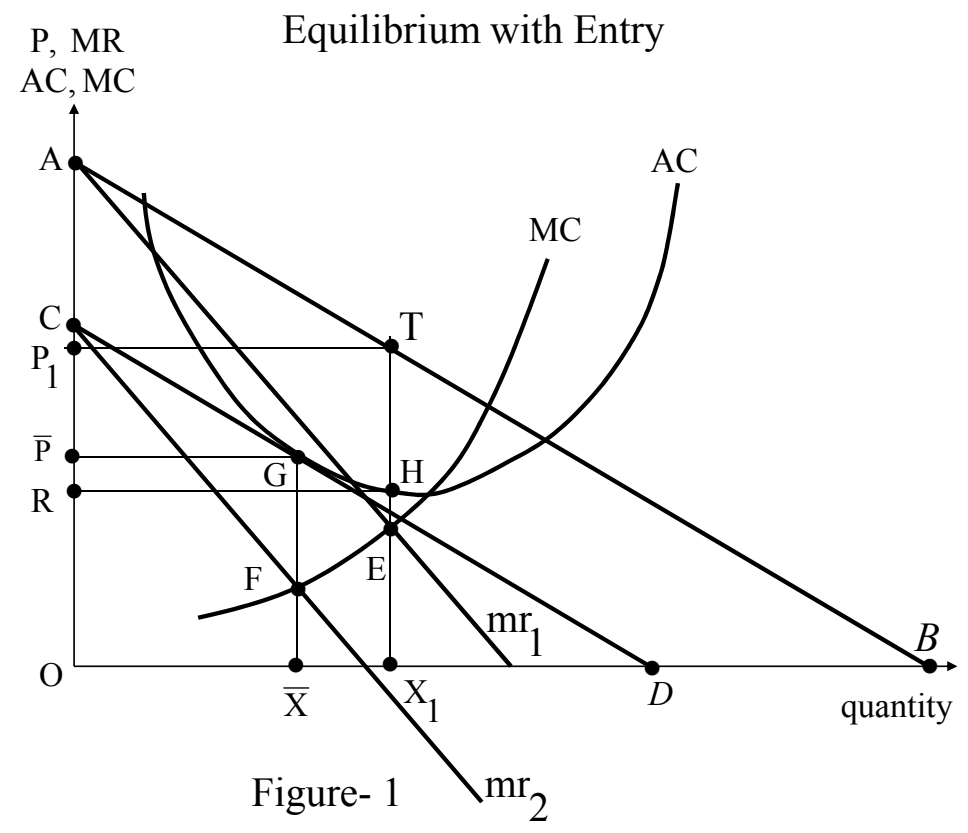

In Figure 2 socially optimum output is $O X^{*}$. The measure of excess capacity is therefore equal to $\bar{X} X *$. That means the firm under monopolistic competition is producing an amount that is less than socially desirable amount. The price charged is also higher than what it should be under perfect competition. 


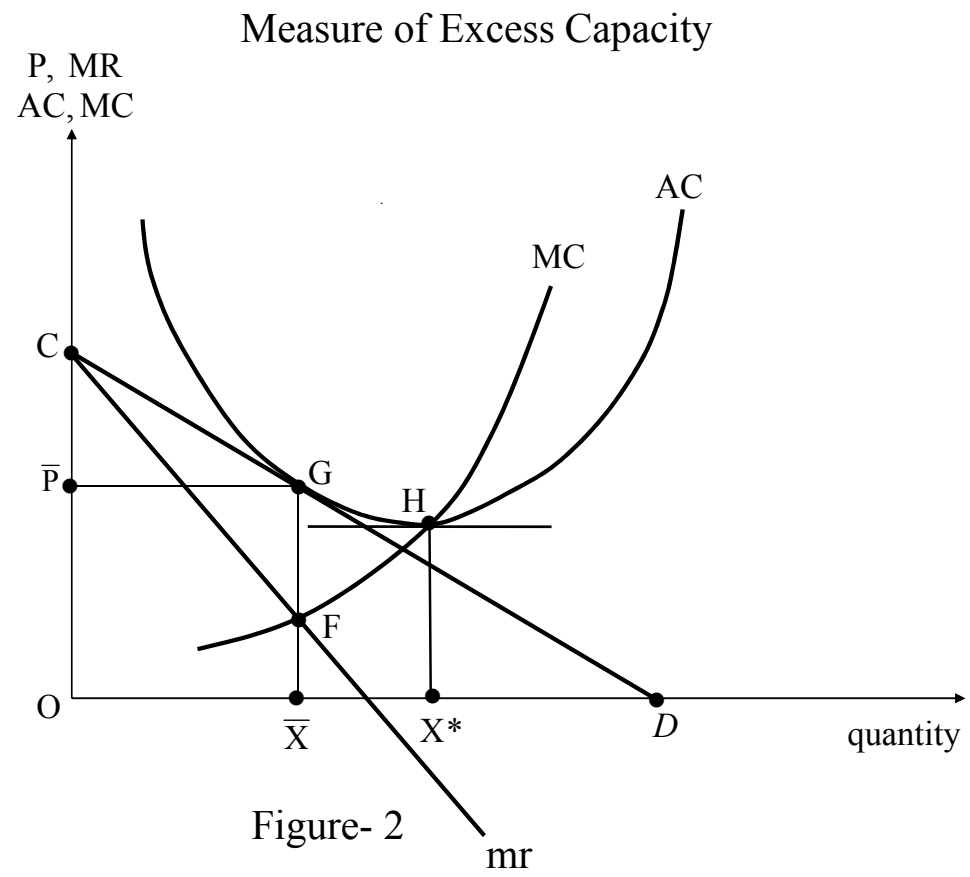

Chamberlin argues that firms under monopolistically competitive atmosphere engage in price competition. With the objective of capturing larger market share, each firm offers price reduction assuming that other firms will not reduce price (Lancaster, 1969). But as a course of action other firms of the group offer retaliative price reduction. Such action results in a relatively small increase in output compared to what has been anticipated by the firms when they reduced price. Figure 3 describes the feature of price competition and the emergence of actual demand curve through the shifting of planned demand curve.

\title{
Model - 2
}

\section{Equilibrium with Price Competition}

\author{
$\mathrm{P}, \mathrm{AC}, \mathrm{MC}$
}

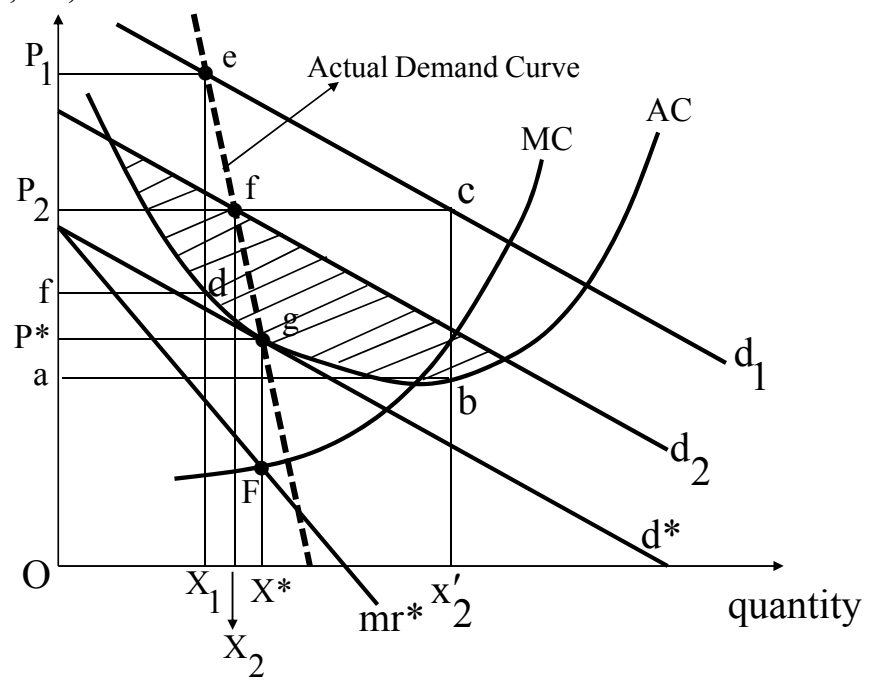

Figure- 3 
Let the Chamberlin's firm operates at point e on the planned demand curve $\mathrm{d}_{1}$ and earns $P_{1} e d f$ amount of economic profit. The firm assumes that its profit could be increased to $P_{2} c b a$ by lowering price from $\mathrm{OP}_{1}$ to $\mathrm{OP}_{2}$. $\mathrm{But}$ at $\mathrm{OP}_{2}$ price its share in market is only $\mathrm{OX}_{2}$ which is much smaller than the expected quantity $O X_{2}^{\prime}$. Because of mistaken assumption regarding other firms' behavior, planned demand curve shifts from $\mathrm{d}_{1}$ to $\mathrm{d}_{2}$ and thereby yielding a point of actual demand curve. In figure the point is f. Chamberlin's firm does not take any lesson from its past mistake, rather keeps offering price reduction as long as the 'Greed Area' appears. The shaded region in figure 3 is a typical form of greed area. Successive price reduction shifts the planned demand curve to the left and the process ends when planned demand curve gets tangent with average cost curve because at that position firms get no incentive to lower price again. In figure, planned demand curve $\mathrm{d}^{*}$ is tangent to average cost curve at point $\mathrm{g}$. By joining the points like e, f and $g$, actual demand curve is drawn. Each point of actual demand curve shows the share of each firm in the market at a certain price. For example, at $\mathrm{OP}^{*}$ price actual share of the firm in market is $\mathrm{OX}^{*}$.

\section{Excess Capacity under Price Competition}

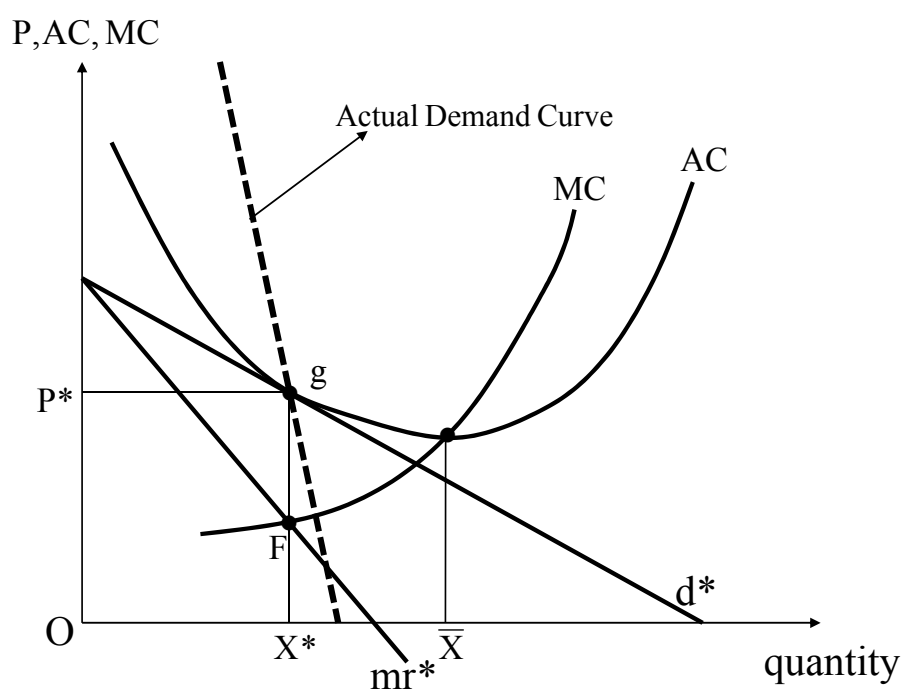

Figure- 4

Figure 4 shows the measure of excess capacity under price competition. Ideal output corresponds to the minimum point of average cost curve which is $O \bar{X}$ in figure but the actually produced output is $O X^{*}$. Excess capacity of the firm is $X^{*} \bar{X}$. The principal limitation of model 2 is the absence of entry and exit of the firms. Chamberlin developed the third model in order to explain equilibrium with both entry and price competition.

New firm's entrance shifts the actual demand curve to the left because of reduced market share of existing firms and price competition shifts planned demand curve to the left. 


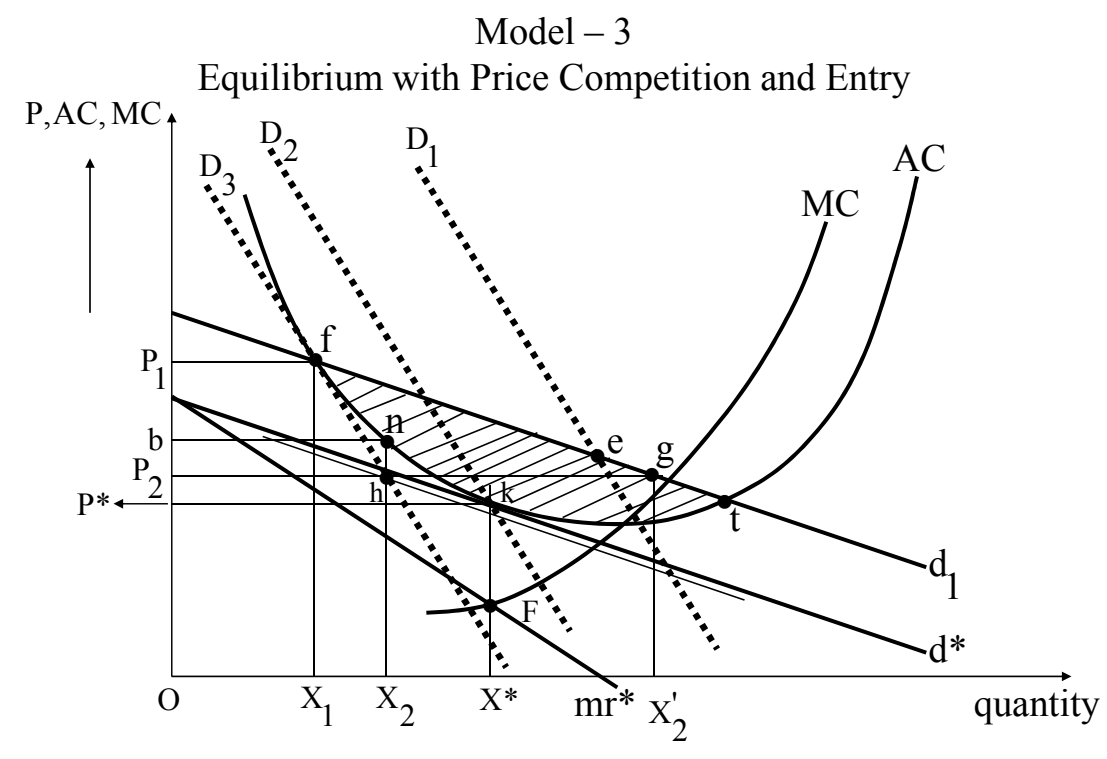

Figure 5

Figure 5 presents the description of equilibrium of a representative firm with price competition, entry and exit. Existence of economic profit at point e provides incentive for the new firms to enter and thereby a leftward shift in demand curve occurs. In figure, demand curve shifts from $D_{1}$ to $D_{3}$. Had there been no incentive for price reduction, the point $f$ would have been the final equilibrium point but the previously defined greed area motivates the firm to offer price reduction and thereby a leftward shift in planned demand curve takes place through which existing firms make loss. This type of loss discourages the financially weaker firms to stay in business. Exit of such firms causes a rightward shift in actual demand curve from $\mathrm{D}_{3}$ to $\mathrm{D}_{2}$. A stable equilibrium is achieved at point $\mathrm{k}$ where planned demand curve is tangent to average cost curve and the actual demand curve passes through the point of tangency.

Sraffa (1926) opines that the equilibrium depicted by accommodating both price competition and entry is quite consistent with real life situation. But still the problem of excess capacity remains present. Figure 6 shows the amount of excess capacity measured by the difference between minimum cost output $\mathrm{OX}_{0}$ and actual output $\mathrm{OX}^{*}$.

Excess Capacity under Price Competition and Entry

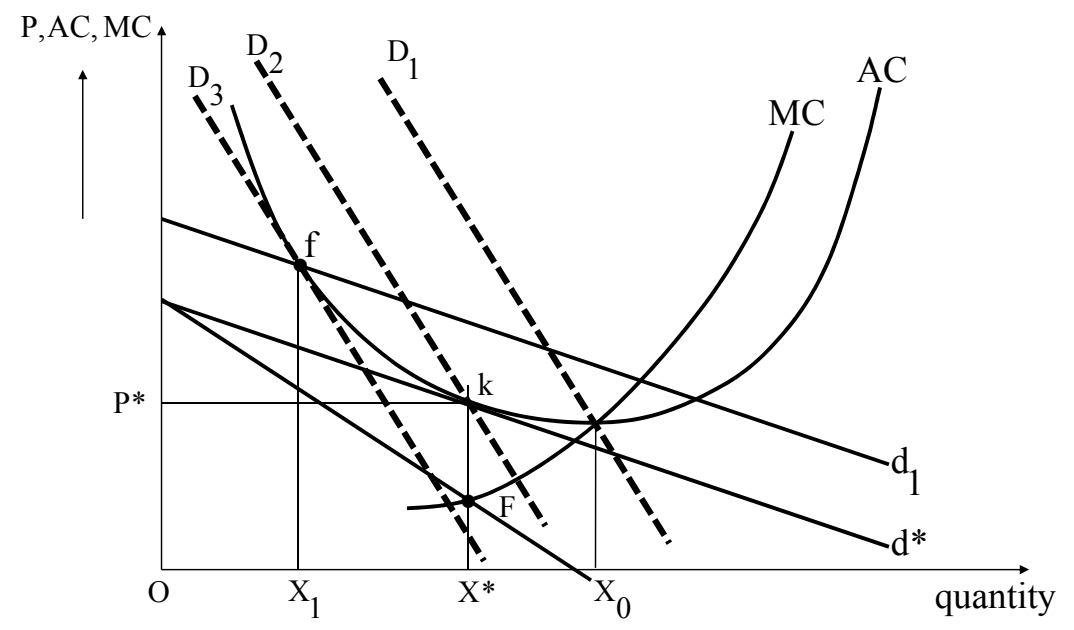

Figure 6 
Chamberlin does not agree with the claim of the above measure of excess capacity. According to Chamberlin, the firms producing differentiated product face downward sloping demand curve and a downward sloping demand curve can in no way be tangent to the minimum point of average cost curve. Therefore, $\mathrm{X}_{0}$ cannot be the ideal output in a monopolistically competitive environment. Chamberlin rather argues that if the firm produces $X_{1}$ amount of output then $\mathrm{X}_{1} \mathrm{X}^{*}$ may be the measure of excess capacity.

\section{Eliminating Excess Capacity- An Alternative Model}

In this section we propose an alternative model of monopolistic competition in which firms are given incentives to produce at a level which is socially optimum and thus excess capacity disappears. Figure 7 may be useful for the purpose of illustration. Actual demand curve $\mathrm{D}^{*}$ crosses planned demand curve at the minimum point of average cost curve. Socially optimum output is $\mathrm{OX}_{0}$. Marginal revenue corresponding to the planned demand curve $\mathrm{d}^{*}$ is mr* which intersects marginal cost curve at point $E$. If the planned demand curve $\mathrm{d}^{*}$ exists then the firm would have earned abcd amount of supernormal profit by producing $\mathrm{OX}_{1}$ unit of output. Contrary to this, if the firm is forced to produce $\mathrm{OX}_{0}$ output then it involves extra $\mathrm{X}_{1} \mathrm{EFX}_{0}$ amount of cost. Of course, due to free entry and exit of firms the supernormal profit will disappear. Therefore, the required amount of net cash incentive that should be provided to the firm to stay at socially optimum output state is

$$
\left(\mathrm{X}_{1} \mathrm{EFX}_{0}-\mathrm{abcd}\right)=\int_{X_{1}}^{X_{0}} M C(x) d x-\text { area } a b c d
$$

\section{Eliminating Excess Capacity - Alternative Model}

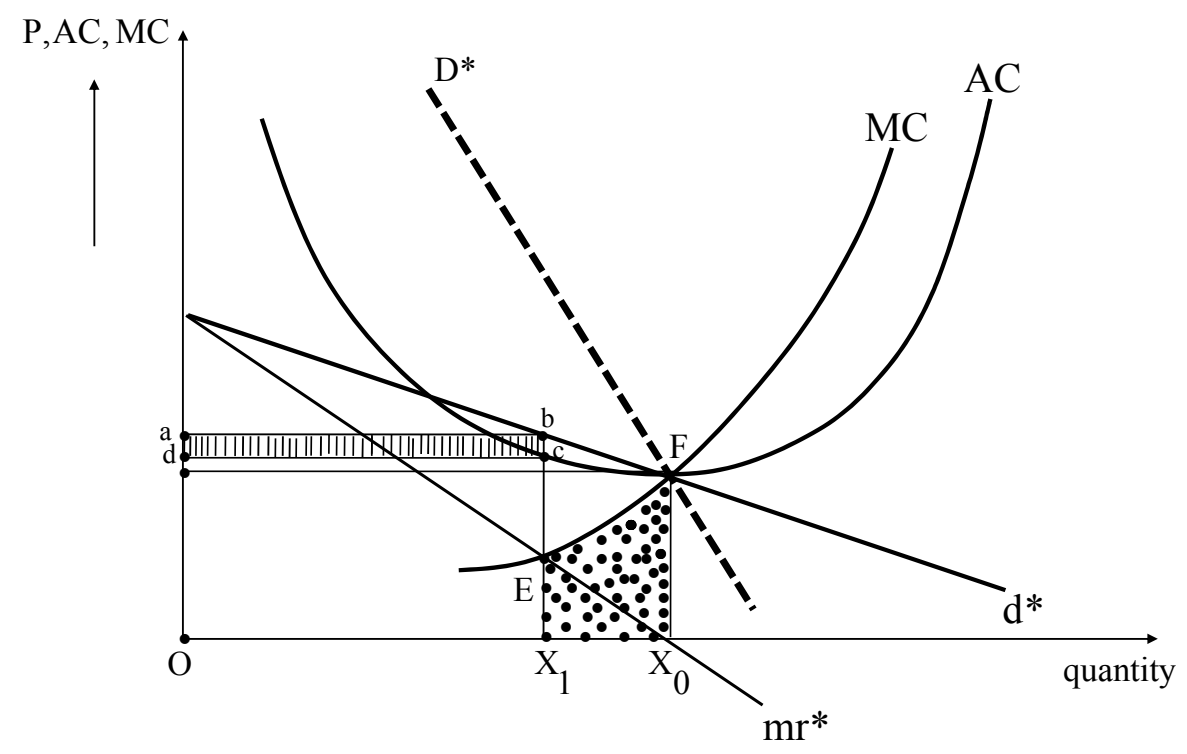

Figure 7

Socially optimum output state would ensure maximum welfare because producers will be producing at a minimum cost and consumers will be able to consume maximum amount at the lowest price. Optimal allocation of resource is ensured at point $\mathrm{F}$ even though the market is monopolistically competitive. Koutsoyiannis (1994) mentions the following four conditions satisfying at point $\mathrm{F}$.

a) The output is produced at the minimum feasible cost.

b) Consumers pay the minimum possible price which just covers the marginal cost of the product, that is, price $=$ opportunity cost.

c) Plants are used at full capacity in the long run, so that there is no waste of resources.

d) Firms only earn normal profits. 
All these features are compatible with the principles of Quran and Sunnah. The rights of both consumers and producers would be well preserved.

\section{Conclusion}

The paper reviews the classical principles of perfect competition and imperfect competition and contrasts them with the corresponding Islamic principles. It is found that Islamic principles of competition are compatible with conventional properties of perfectly competitive market structure. Conventional economics explains the adherence of imperfect competition to social welfare loss but it does not have any say regarding the prohibition of imperfect competition. Islamic economics, on the other hand, does not allow imperfect competition, rather prohibits the monopolization of the business. The current paper discusses the nature of a special variety of imperfect competition, namely monopolistic competition. This type of market structure is more realistic than any other variety. The markets of most of the products used to meet daily needs are monopolistically competitive. Under the real life circumstance, it is not possible to abolish this type of market structure. Effort should rather be put to harmonize Islamic principles with monopolistic competition and bring necessary correction in the conventional treatment of this form of real life market structure. E. H. Chamberlin was the proponent of monopolistic competition who developed three different models for describing equilibrium of monopolistic competition. The principal limitation of all models is the existence of excess capacity. Each firm produces an amount which is less than socially optimal level. This paper presents an alternative model of monopolistic competition in which excess capacity disappears. Firms employ optimum plant, produce socially optimum amount and sell at a minimum price. This of course requires the planners provide incentives to the firms.

The key limitation of the paper is that it does not specify the source from which the incentives would be supplied to the firms. Also the nature of incentive, whether it is in the form of cash or kind, has not been mentioned. The aforementioned issues are beyond the scope of this paper. Further research may be carried out to investigate what kind of incentives may induce the firms to produce socially desirable amount of output. If the firms can be made aware of their ethical, moral and social responsibilities then they will not deny to produce socially expected amount of output.

\section{References}

Andrews, P. W. S. (1964). On Competition in Economic Theory. Macmillan, New York. https://doi.org/10.1007/978-1-349-81682-8

Baumol, W. J., \& Blinder, A. S. (2005). Economics: Principles and Policy. Cengage Learning, New York.

Chamberlin, E. H. (1933). The Theory of Monopolistic Competition. Harvard University Press.

Choudhury, M. A. (1986). Contribution to Islamic Economic Theory. Macmillan Press Ltd., London. https://doi.org/10.1007/978-1-349-07728-1

Ghani, I. M. A. (2003). Some Thoughts on the Interface between Copyright and Competition Policy. The Malaysian Perspective, 2, CLJ 18.

Hawkins, C. J. (1972). Theory of the Firm. Macmillan. https://doi.org/10.1007/978-1-349-01060-8

Koutsoyiannis, A. (1994). Modern Microeconomics. ELBS with Macmillam.

Lancaster, K. (1969). Introduction to Modern Microeconomics. Rand McNally International Publishing Company.

Mannan, M. A. (1984). The Making of Islamic Economic Society. International Association of Islamic Banks.

Sraffa, P. (1926). The Laws of Returns under Competitive Conditions. Economic Journal. https://doi.org/10.2307/2959866

\section{Copyrights}

Copyright for this article is retained by the author(s), with first publication rights granted to the journal.

This is an open-access article distributed under the terms and conditions of the Creative Commons Attribution license (http://creativecommons.org/licenses/by/4.0/). 